\title{
VASOMOTOR ATAXIA: A CONTRIBUTION TO THE SUBJECT OF IDIOSYNCRASIES. ${ }^{1}$
}

\author{
BY Solomox Solis-Cohen, M.D., \\ PROFEsOR of CLISTCAI, HEDICTYE AND APPLIED THERAPEOTIC IS TIE PHILADELPIIA

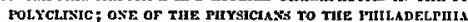 \\ Matipital, ETC.
}

TuE preseat paper is iateaded merely as a record of personnl observations, aad preseatation of conclusions based thereon; it will aot, therefore, refer to facts and theories in literature, though many observations parallel with, nnd confirmntory of, the views expressed lave heen found. The exigeacies of time necessitate citation of a few oaly of the cnses studied, which, excludiag the more numerous instances of slight depnrture from the norm, altogether number sixty odd, accumulnted in hospital and private practice during tbe course of some eigbt years; aad such reports as are mnde must be brief. I would request, therefore, that it be assumed, in discussion, tbat despite brevity of account these cases have beea investigated from all standpoints with as much thoroughness as I am capable of, or as the opportunities permitted.

The varying susceptibilities of different individuals, and of the same iudividual at different times, to the snme iaflueaces has long been a matter of everg-day observation. Of a aumber of persons exposed to cold and wet nt the same time and place, one may have articular rheumatism, another pneumonia; one tony coatract tonsillitis, another nephritis; otbers mny escape appareatly unharmed. Evidently there is something at work in addition to inclemeat weather and specific microbes; and this something, which is the determiniag and tberefore the principal etiological fnetor, is special to the individunl-is a physical persoaal equation. We call it, whether exbibited in relntion to the exciting causes of disease or to the action of drugs, individual liability, predisposition, idiosyncrasy; and though our terms are siagular in type, we recogaize that the siagularity is relntive and mny be exhibited by severnl persoas.

For every idiosyncrasy there must he n physiological basis. By comparing the pheaomean, special aad geaeral, exbibited by a group of persons preseatiag similnr or identical idiosyncrasies, we take $\mathbf{n}$ step townrd the recognition of the hasic physiological couditions.

I would iavite attention to an irliosyncrasy of the circulatory mechaaism, which, in its extreme degrees, maaifests itself in the form of well-recognized symptom-complexes; in its minor degrees gives rise to puzzliag maaifestations of great variety of detail; and in its least-

\footnotetext{
1 nend before the Section of General Jedleine ar the Fint 1un-Americau Medical Congress, held at Washingtod, D. C., September, 1593.
} 
developed forms often passes unnoticed. For this condition-which seems to depend upon a feebleness in the co-ordinating mechanisnis in consequence of which the balance of the cardio vascular action becomes disturbed by infiuences that in the grent majority of persons have no such effect, nnd greatly disturbed by influences that normally have sligbt effect, while the restoration of equilibrium is slow and imperfect-I would propose the self explanntory name of vasomotor ataxia: ataxia rather than byperkinesis, or b ypokinesis, because excessive vascular dilatation and excessive vascular constriction may be either spasmodic or paretic, or both spasmodic and paretic, as dilator or constrictor nerves, or botb, are affected; nnd even in the extreme nnd opposite types of vasomotor ataxia, tbe phenomena, while nlwnys more or less paroxysmal, are neither exclusively those of dilatation nor exclusively th ose of constriction, but botb ahnormal dilatation and abnormnl const riction are usually present in varying degree in the same patient. The influences under which these phenomena are displayed nre, inore especially, temperature-and cold more tlian heat-emotion, visceral or internnl reflex excitation, nnd the nction of toxic agents formed in the orgauism or introduced from without.

The most striking and easily recognized phenomena are those exbibited by the heart and hy the peripberal ressels (arterioles, capillaries, and venules); but analogy indicates that similar manifestations occur in the vessels of glands nnd viscera, while certain symptoms are only to be explained by disturbance of ccrebral circulation. The stimulus that results in cardiac and vascular disorder may be npplied centrally or peripherall $y$, but the defective inhibition upon wbich the pbenomena depend must be relatively central, and is probably the expression of functional or nutritional defect in the great ganglin of the sympathetic system, or in the medullary centres, or in both.

Functional nnd nutritional disturbnnce may result in structurnl, and finally in organic change; but the discovery of gross anatomical change at necropsy would not prove that it had existed from the first. It is likewise to he borne in mind that functional, nutritional, or structural defect in the sympathetic ganglia or nerves nany be primary, or the result of primary or secondary disease elsewbere. The phenomena of vasomotor ata xia may thus occur independently, or be merely a part of the symptomatology of functionnl nnd organic diseases of various kinds. In either event the mechanism is essentially the same, and it will facilitate study to consider the circulatory symptoms apart from other complicating conditions.

With the pronounced types of vasomotor ntaxia, to whicl nt the one extreme-that of vascular relaxation-the name of Graves's disense or exopbthalmic goitre, nnd nt the other extreme-that of vascular tetany - the name of Raynaud's disease, local syncope, local asphyxia, acroaspbyxia, symmetrical gangrene, acrospbncelus, etc., bave been given, all 
are familiar. All nre familjar, too, with the association of other phea oruena of vasomotor paresis or vasomotor spasm with Graves's diseage and with Rayaaud's disease. For example, nagiaa pectoris occurs ia hoth, and angioaeurotic cedema and spoataneous gangreae have heea observed in Graves's diseuse. As pointing toward more than n superficial or accideatal resemhlance in such association of the two nffections, the followiag two cases are suhmitted :

Case I. Aero-asphyxia, with intermittent enlargement of thyroid gland, and paraxysmal tachycardia. Sarah O'N., unmarried; seamstress; aged twenty-five yesrs; native of Ireland; having fair skin, brown eyes, hlack hair; was seen at the Philadelphia Polyclinic, April 11. 1892. For three or four months she has had almost constant headacbe, with occasional dizziness. Vision at times misty. The feet sometimes swell. At times she has pain in the precordium, with cardiac palpitation. These attacks occur paroxysmally. For ahout two years she has noticed that several times a day, especially if exposed to cold, either hy immersion in cold water or otherwise, the fingers auddenly hecome discolored-purplish. Both extremities are affected at once. The discoloration begins in the palm of the hand, and extends downward. It lasts hut a few miautes, and disappears quickly. The first phalanx of the middla finger of the right hand is thickened, the skin glossy, tha veins much distended. Thera is a depressed cicatrix on its inner aspect. The patient states that twelve years ago there was a swelliug at this place, which was lanced, and kept oa discharging until within a fer months, whea the sinus finally closed. The howels ara constipated. The patient does aot rise at night to micturste. Irenstruation is irregular. Examination shows nll orer the arms mottled areas of irregular distribution, indicating by their rarying color, and by tha appesranca of the distended vessels, both capillary and venous coagestioa. Oper the upper part of the chest, anteriorly and in the hacle, especially beneath the scspule, are congeries of distended superficial venules. The legs and feet appear aot to be affected. No lesion of the lungs can he detected. At tha first examination of tha heart the rate is 96 . At tha base a soft systolic murmur is henrd, more distinctly on tha left. In the veins of tha neck a marked musical hnm is heard, louder on the right. It is contiauous, with systolic intensification. The thyroid gland is easily demonstrated, but ant markedly ealarged. Hiemoglohin is 65 per cent. by Fleischl's scale; red corpuscles number more than $4,000,000$; there is no excess of white cells. Urine is I018, acid; no albumin, no sugar, no casts, ao red cells (Dr. Esh ner). The fundus of the eye is aormal; there is compound byperopic astigmatism (Dr. Jaclison).

Relief of constipation, together with correction of visual error hy glasses apparently relieved the hendaclie. After a few doses of nitroglycerin, the local asphyxia did not return while the drug was tnken.

Some three months later the patient returned, complnining of recurrent headache, with attacks of precordial pain and violent palpitation. The naturc of these attacks seemed to be that of tachycardia rather than gimple palpitation. While under examination the pulse-rnte was variahle, ahout 130. Tbe thyroid gland was slightly enlarged, and a bruit could be heard over the gland on auscultation.

Picrotoxin, fo grain t.d., was prescribed, with apparent relief to headache. During some ten weeks the thyroid was ohserved to enlarge and diminish irregularly, without reference to menstruation, which occurred twice during tha period. The swelling was soft, not expansile, and greatest on the right side. The patient was last seen some four months ngo, when the thyroid gland was apparently normal ; pulse-rate 96.

CASE II. Epilepsy; acro asphyxia ; enlargement of thyroid gland.-MIary N., aged nineteen years; domestic, unmarried; of American hirth. Irish parent- 
age; fair skin, hrown hair, hlue eyes; seen at the Philadelphia Polyclinic, January 4, 1893; has had mild epileptic paroxysms of ahout one half-hour's duration once a veek, since the preceding Octoher. There is no aura. She screams and turns pale hefore losing consciousness. The bowels are regular; the meases regular hut psinful. The patient is suhject to paroxysmal flushing, with suhjective and ohjective hent, especially of the face. There are irregular sweats. She has nrticaria in summer-time. She is easily excited; and has frequent attacles of palpitation and rapid thumping of tbe heart. The heart is not enlarged; the impulse is jerky; the rate is 100 ; the first sound is short, the second sonnd is nccentuated at the aortic cartilage and at mid-sternum. There is n soft systolic murmur over the sternum, near the articulations of the second cartilages; it is not transmitted. The thyroid gland is enlarged, especially in the right lobe; it is soft and pulsating; there is no thrill and no hruit. The hands are of a dusky-hlue color, which slowly fades on elevation; the nails are purplish. Upon immersing the hands in ice-cold water they soon hecome red. If one hand only is placed in the cold water, that one becomes red, the other a deeper blue. Dermographism is marked. Factitious urticaria is produced hy pressure, followed hy cold.

The patient states that only recently has she noticed occasional blueness of the hands; that it is not constant, and is usually produced by cold, but may come on while at work in a warm room.

There are on the cheeks of this patient tbree or four small reddisb elevations, surrou aded by little radiating lines-a star, as it vere-of dilated vessels, $A$ number of small telangiectases are found on the arms and hreast. Sbe states tbat sbe bleeds ensily if cut, but blood is stanched in a ressonable time. She frequently bleeds from the nose. No family bistory is attainable.

Taken hy thenuselves, these two cases might not nppear to be of specinl significance; but to me they were of great interest, because they seemed to supply the links between two groups of cases that had occupied my attention for a number of years, and which $I$ believed to be related to each other, as to Graves's disense in the case of the one group, and to Raynaud's disease in the case of the other group; and thus to complete the chain of observation, as of reasoning. This will become more apparent if I relate briefly, hut in some detail, the case that first drew my thougbts to the subject.

CASE III.-In February, 1885, Miss X., of American hirth and parentage, Hehrew race; fair complexion, hrown hair, gray eyes; an intelligent and truthful, and not hysterical young lady, some seveuteen or eighteen years of age, apparently in perfect health, was alarmed at a sudden dimness of vision, progressing in the course of a few minntes to total hlindness, which lasted "ahont a second." The return of sight was followed by intense beadache, lasting about ten minutes. Ophthalmoscopic examination, some hours afterward, and at different times since, has never detected any ahnormality.

Examination of the arine passed the morning following this attack showed tbe presence of a quantity of alhumin too slight to he quantitatively estimated, a few leucocytes, a few uric acid crystals, many red hlood-cells, and in one or two felds a hyaline tuhe-cast, or a mucous cast. This condition lasted for two or three days. The nrine was acid in reaction, and 1015 to 1018 specific gravity; the quantity was normal. Inquiry revealed the fact that the patient blushed easily, and that in addition, withont known emotional cause, tbere occurred at times what she termed "burning flashes," in wbich the skin at various areas, sometimes circumscribed, as to a cbeek, sometimes generalized, would for a few minutes, or a few hours, become intensely red, with both subjective and objective sensation of beat On one or two occasions the peculiar distribution of tbe red areas and their persistence for a day had led to a false domestic diagnosis of measles. Buttberepetition of the attacks, their 
peculiar derelopment and conrse, and the nbsence of all other morhid phenomens, 800n proved theerror. As a child, too, she was gaid to have had measles three times and ruhells once. In one of these nttacks that I saw, as the rash was fading, the skin of the arms, chest, nnd neck was covered with little pink spots, not elerated ahove the snrfice, the largest of which was no larger than nn ordinary pin-head; and $I$ was told that the rash began in the same way, hut that when at its height it presented either as a uniform scarlet flush, or the mottled appearance simnlating measles. On annther occasion I gaw the patient when the right cheek was the seat of a vivid hlush, the left heing npparently normal, and was told that the left cheek had heen the hlushing one some hours earlier. The fushed right cheek had a surface temperature of $97^{\circ} \mathrm{F}$., the left cheek $95^{\circ} \mathrm{F}$., while the axillnry temperature was $98.4^{\circ} \mathrm{F}$.

Orer the middle portion of the lefo lower jaw this patient' 8 s kin invariahly presents during menstruation an ares of fxed hlushing; that is, it is reddened in nn oval patch about tro inches long nnd half an inch wide, the color being deepest in the centre, and fiding at the periphery into that of the surrounding skin. Her nails are slightly conver, pink in color, longitudinally striated, and exhibiting crescentic markings. She bas heen under ohsersation continuously since the attack of hlindness recorded, nnd during that time has presented, in addition to the flusbes spoken of, an attack of ery themn nodosum; several attacks of urticaria; one attack that $I$ did not see, which appears from her description to have heen a circamscript cedema of the arm; nnd one that I did see, which was circumscript cedema of the calves of the legs. The transient blindness bas heen repested, affecting only one eye, howerer, and there was one attack of hemiopia, likewise transient, in which she did not determine which eje was affected, or whether both were involved. In 1889 un nttack occurred, which (my notes heing defective) she describes as follows:

"Having been in good bealth for two years, I awoke one night with a great desire to urinate; this was followed by a feeling of faintness nnd great pnin in the heart-I must have been purtly unconscious, as I walked down stain without rememhering how. When $I$ became awnre of my surroundings, there was intense itching of the palens of the bands and soles of the feet, and $n$ trembling of the whole hody, which, for some minutes, I was unable to control. In the morning there was a red bloteby appeurance on the chest, lnsting sereral honrs, and welts on the wrists. I felt well, nnd had no pain. I remember that the urinalysis for the next six months frequently showed ulbamin, hut I felt perfectly well and strong. "The rash and the welts occasionally appeared."

The urine is for monthis normal. hut occasionally shows a trace of ulhumin, uric acid crystals, casts, cylindroids, or hrmocytes. Sometimes all of these will he found together, sometimes albumin only, or hlood cells only. General health and strength keep good, the eyes are emmetropic (Dr. Jackson), with large pupils, and the hlood is normnl. Though there nre occnsional attacks of palpitation, the heart, and so far as $I$ can determine, the lungs and nll the other viscera - for I do not heliere there is organic renal disease-are normal. Menstruntion, however, is irregular nt times, nnd there is occasional dysmenorrbca. The attacks described are not related with menstruation. The thyroid gland is demonstrahle, hut not enlarged.

The family bistory in this case is of great interest. It can lardly be n series of meaningless coincidences. The patient's father died of ncute pneumonin, nfter baving for forty years suffered with pulmonnry hemorrhnges, nttributed to "disease of one lung," of wbnt nnture I do not know. Several pnternnl cousing bave leucodermn; one has bad renal colic, passing uric ncid gravel; another, highly myopic, has obscure symptoms of disturbance of the sympathetic nervous system, diagnosticated by one observer as incipient Graves'a disease; another has bnd chorea, nnd is very liable to epistaxis and to pannris; nnother, likewise lighly myopic, 
has: had retiunl hemorrlinge; another has chilhlaias every winter, and is subject to suddea syacope from slight indigestion; noother has hlueaess of the hnods evcry wioter, with tendeacy to deep fissuriag of the fingertips, unless constantly prutected hy woollea mittens; nnother will get circumscript œdemn from slight kaocks thnt in nthers would pass unnoticed, and thnt evea ia him do not cause discolnration of the skia. A pnternal aunt, still liviag, is affected similarly to the father. A hrother of the father's died at the nge of thirty, of suffocntion in the course of n pulmonary hemorrhnge. His son has prngressive myopia of high type. There is likewise $n$ rheumatic teadency in this family; ooe of its members has had diahetes mellitus. The patient's mother is liviag and healthy, at past sixty years of nge. Severe mental shock, however, not long ago prostrnted her in hed for a few days, duriag which time the henrt's nctioa was feehle, excited, and irregulnr; the temperature was slightly subaormal ; nlbumin, tuhe-casts, red aad white hlood-cells were found in the urine. I am satisfied that she has no organic lesion. Several memhers of her family have hnd dinbetes mellitus-living, however, to advanced age, and two of her sisters and one niece have hnd carcinoma of the hreast. There is also a gouty and a neurotic heredity in this fanily.

As further exhibiting the essentially constitutionnl basis of vasomotor ataxia may he briefly stated:

CASE IV.-A brother of the preceding patieot, aged thirty tive years, darkhaired, blue-eyed, has bcen for some eight years the subject of ophthalnic migraine, and bas attacks of spasmodic asthma if exposed to the emsnations of feathers, or to moist ntmosphere at the seashore. He has hyperopic astigmatism (Dr. Gould). His thy roid glnod is slightly enlarged. He exhlbits aloog the borders of the ribs the peculsr appearance which I have termed the costal fringe, oamely, a netwnrt of telangieetases, followiog the outlines of the costal arches. This apperrace is found in some cases of hepatic cirrbosis, but this pstient's liver is apparently normal. He has no pulmooary or other visecral lesion, but is seized nt times with gastric erises (pain relieved by vomiting), that appear to correspond with periods of lithuria aod oxaluria. His urine has aever showa alhumin or cast3; aod red hloodcells have been found on hut one occasion. His reflexes are normal, or perhaps slightly exaggerated.

These two patieats, and a sister of theirs who is suhject to profuse epistaxis, oceurring without appnrent cause, hut is otherwise healthy, exhibit three symptoms upon which I vould lay special stress:

1. Dermographim. That is to say if, with a hlunt prohe, nad using very light pressure, letters or other device he traced upon the skin of the patient, especially upon the inaer aspect nf the limhs, or over the sternum, the traciags sooa appear ia $\mathrm{n}$ rosy-red tiat that lasts for some minutes, or even hnlf nn hour.

2. Factitious urlicaria. If in tracing upon the skin one uses a littledeeper pressure than hefore, the red lines sonn hroaden, nnd fially the reddened portions show a more or less decided elevation, like the wheals of urticaria. In some cases the red color fndes, in others it persists. The 
elevation remains in some instances, notahly iu cuses of chorea and of exophthalmic goiter, for several hours. When factitious urticaria is nut immediately apparent upon the use of pressure merely, it may in some cases he quickly developed hy applying cold to the part, as with a lump of ice; in other cases the npplication of hot water will cause it to appear. When cold or heat is applied, the wheals are always reddened, and sometimes a diffuse redness that slowly fudes is likewise seen upon the intervening skin.

3. A modified form of Stellwag's eye-sign of exophthalmic goitre. When the patient looks fixedly hefore hin, and opens the eyes, a distinct white rim of sclera is exposed ahove the cornea. It may he spontaneously exlihited in the excitement of conversation, or may have to he developed hy the physician in the course of examiuation.

I lay stress upon these signs on account of their occurrence in Graves's disease. Unfortunately I have not heen systematically employing these tests for much more than a twelvemonth, during which time $I$ have not seen a large number of typical cases of exophthalmic goitre. I have records, however, of seven undouhted cases (one male, six females), in which dermographism and factitious urticaria were marked; and, in. deed, I have never seen fuctitious urticaria so readily produced, so persistent, or so striking, as in the case of a colored woman with exophthalmic goitre, in the wards of one of my colleagues at the Philadelphia Hospital. I may hriefly record in this connection, as a case linking the preceding ones with those to follow, a case from my own service at that hospital:

CASE V. Exophthalmic goilre with acro-auphyzia.-(Notes taken by Drs. Claribel Cone and S. Stivers, resident physicinns, Philadelphia Hospital, February 23, 1893.) Charles P., aged thirty-three years; waiter; native of Ireland; unmarried. His mother died of cancer of the hreast, his maternal grandmother, of cancer of the nose; $n$ maternal cousin, of phthisis. There is no neurosis in the family. The patient had the infective fevers of childhood. He has heen a hard drinker. He had syphilis and gonorrhoes nhout twelve years ago. He has not had rbeumatism. When a child he had attacks of palpitation of the heart, wbich ceased as he grew older. Twelve years ago he was occasionally attacked in the same way. Six years ago, after $n$ dehauch, more persistent rapid action of the heart developed, and has continued nt intervals since. Attacks may he hrought on hy his being startied. The cardiac disturbance sometimes prevents sleep. It is accompanied with dyspnea. There is no cough. For the same length of time he has heen very n ervous, easily frightened; his hands tremble, and at times there is a general tremor. The cardiac storms and general nervousness develop syuchronously. He has occasionally spit hloodnot sufficient to cause him to give attention to it. The present attack hegan ahout a month hefore admission. There is no pain, no andsthesia, no motor paralysis. The eyes were always large, hut have heen getting more prominent for the last two years. Graefe's and Stellwas's signs are hoth present. Goitre has appeared and disappeared; no data of this are attainable. At present there is no demonstrahle enlargement of the thyroid gland. The pulse-rate varies from 81 , under treatment, to 140 withont treatment. The cardiac impulse is not strong. There is no mnrmur. In the vessels of the neck, especially the jugulars, there is a marked musical hum. Examination of the blood shows: Hamoglohin (Fleischl's scale), 30 per cent.; red corpuscles, 4,036,000; 
white cells, 11,000. There is no pulmnnary lesion. There is nothing abnormal in the urine. The patient has frequent cold aweats. The skin is usnally warm and moist. The hands, from time tn time, hecomo hluish and cold. They are always moist. At times, after an attack of coldness and lividity, they hecome pink and warm. The attacks are independent of weather, and of the temperature nf the ward, hut can he induced by exposure to cold. The duratinn is variable. The patient has an irregular temperature, hut no relation can he traced between temperature eurve and paroxysms of acro-asphyxia. Dermograpbism and factitious urticaria are marked. The hands immersed in warm water $\left(110^{\circ} \mathrm{F}\right.$.), hecnme slightly red in nhout three minutes. In cold water $\left(40^{\circ} \mathrm{F}\right.$.) they become quite red in two minutes. One hand heing placed in cold water hecomes red; the nther, left free, hecomes blue. White spots made hy pressure on the hluish or reddened skin remain for a long while. Elevation reduces lividity slowly, hut has nn effect on the pinkigh discnloration. The patient exhibits telangiectases at different portions of the trunk, and has a bard, pinkish, gessile growth ahout the size of a hean, on the left cheek.

Incidentally, it may be remarked that this patient professed to feel hetter and exhibited slight objective improvement during the administration of desiccated thyroid gland. The only ahuormality ohserved in the urinewas during this time, and consisted in an intense hlood-red colnration. It did not respond to tests for hemoglohin, and Dr. John Marshall kindly examined the specimen, and reported the color to be due to a modified form of indican.

Bearing the foregoing case in mind, the ohservation now to he recorded finds its place and explanatiuu. The cuse is in many respects similar to one that I ohserved in 1886 , at the Jefferson Medical College Fospital, and in which Prof. Bartholow concurred in my diagnosis of vasomotor paresis, as ngaiust cardiac hypertrophy. In the earlier case acroasphyzia was not present; temperature was elevated during paroxysma of fushing of the face. There was much headache.

Case VI. Humoptysis; tachycardia; acro-asphyxia.-I. H., aged sixteen years, of Russian hith and parentage; Hehrew rute; dark skin, hair, and eyes; a poor hoy, who during the day teaches Innguages to beginners, and at night, in a cold room, studies tn tit himself for tollege, was sent to me hy his attending physician, Dr. C. D. Spivak, February 26,1893 , with n note stating that fnr a week he had had daily bemorrhages, slight ia amount, believed to he pulmonary, the hlood heing hright red and sometimes mixed with saliva. There was no cough, no expectoration. Physical examination revealed no pulmonary or laryngeal lesion. The heart was rapid (130) and forcihle, hut not demnnstrably enlarged. The first sound was somewhat short, the second sound accentuated. The pulse was tense. The hands were discolored, the terminal phalanges heing of a deep purple, the rest of the fingers and the dorsum of the liand being af various shades of pink, red, and hlue, the palms heing mottled red and hlue. Elevation slightly lessencd the colnr, and secured a more even distribution of shsdes. The thyroid gland was sliglitly enlarged, and there was a faint hum in the ressels or the neck. Tbe pupils were widely dilated, and there was evidently grent eye-strain; the patient complaining of headaches hrought on hy reading, and the left eye slowing a tendency to wander. Later in the case, Dr. George DI. Gould kindly examined the eyes, and found a high degree of componnd hy peropic astigmatism, the eye-ground heing normal. The urine has nevcr contained nlhumin or casts, and red hlnod-cells were found on but one occasion.

The patient was put to hed, with regulation nf diet and secretinns; ice was applied over the heart, and tincture $n f$ aconite given until the pulse fell to 60 . In the course of a week he was permitted to rise, when the pulse immediately shnt up to 100 . Dark glasseg nnd paralysis of accnmmodation, adopted at Dr. Gould's suggestion, failed to quiet the heart. Suitahle glasses were then prescribed, and aconite again administered until tlc pulse, in a 
sitting posture, fell to 80 . On stopping the aconite, tachycardia again manjfested itself. Examination of the n rine shnwed nothing ahnormal. Examination of the blood showed corpuseles and hamoglohin ahout 75 per cent. The accentuation of the second heart-snund, and the high pulse-tension now receired the consideration that perhaps they ahonld have had earlier. Aconile was stopped, and nitroglycerin given in ascending doses until physiological cfiect was manifested. The pulse-rate fell to 80 in the sitting posture, 90 in the standing position. It was still further increased upon exertion. Aconite was now given in conjunction with nitroglycerin, and tincture of chloride of iron administered concomitantly. Under this treatment, with gradually decreasing doses of aconite and nitroglycerin, the pulse bas become steady at about 80 . There has heen no further hemorrhnge. No sign of pulmonary lesion is to he discovered. There has heen nohistory of rheumatism. While in the house, the room heing kept warm, the discoloration nf the hands faded to a light duskiness. While going about in cold weather, the condition pre. viously described returned. The hands sweat profusely at all times, eren in cold weather. Since warm weather bas set in the hands have become normal in appearance. The patientexhihits dermographism, factitious urticaria, and the eye sign already described. The pupils are persistently and equally large.

CAsE VII. CElemalous acro-aspyxia. -The h rother of the preceding patient, a peddler, a native of Russia, aged twenty-th ree years; is suhject to chilblains. I had ooe opportunity to exomioe him-July 17, 1893-0 warm day. The hands were of o dusky culor, mottled red ond hluish; the nails purplish, and exhibiting the peculior crescentic morkings. There was coosiderable sweatiog of the hands; be says that they get almost block iu cold weatber, ond sometimes when not cold. At times they suddenly swell, ond then often hecome dark blue. The swelling lasts a few bours, rarely a day. Sometimes there are white patches oo the baods when they are otherwise blue. The duskiness preseot on the occasion of my exomiootion lesscoed on elevation. The heart was stroog; there was no murmur; pulse 84 in sittiog posture, somerwhat tense.

There was mydriasis; the sclerotic was exposed upoo openiog the eyes. Dermographism and factitious urticnria were present. The baods trembled oo beiog beld out for 0 short time. This was sald to be of frequent occurrence. The thyroid gland was not demonstrahle. There was no history of cardiac palpitation. This patient likesise has hyperopic astigmatism.

Additionol cases migbt be narrated were it necessary (and some will be puhlisbed bereafter), in which what we may, for convenience of designation, call the Groves group of pbenomena nnd the Roynuud group of phenomeno are mingled in varying degree. But tbose selected are sufficieotly indicative of the gradual transitions by which two diseases, npparently so opposite in their nnture, mny be brought under one clinical generalization. Leaving now the Groves group, nnd those cases thot stand on the fur side of it, $I$ desire to briefly submit some interesting cases on what we may call the hither aide of the Raynaud phenomeno; arid it will be found, I think, that gradual transitions moy also he traced here down to normolity, which, like the sigil, completes our ring.

Case VIII. Anamia; hamatemesis; gastric ulcer (1); acro-asphyxin.-Mary T., aged seventeen years; of American birth and Irish parentage; fair skin. dark hoir, gray eyes; syphilitic inheritance; was under my care in 1888, for profound anxmio with hæmatemesis and symptoms suggestive of gastric ulcer, and recovered under treatment hased on such a dingnosis. Early last vinter she returned, rosy in bue, without anæmia, hut again complain. ing of spitting hlood. Her handa were of a deep-hlue color, which was 
unaffected by position. I scnt her to a friend to have ber hands sketched, and on the way to his office they resumed a normal color. Frequently during the cold weather they would hecome red or blue, or mottled red and blue. On severe exposure they once became dend white, and were excessirely cold. When blue, the bands are subjectively and ohjectively cold; when red they are ohjectirely warm, hut suhjectively cold. Thesame changes tnke place in the feet. Both hands and feet sweat profusely. Capillary pulse was seen in the lips and nails. Occasionally she hns a film before her eyes. There is no lesion of the eye-ground, hut glasses are worn for relief of headache (myopic astigmatism, Dr. Jackson). There is no cardiac or pulmonary lesion. The thy roid gland is not abnormal to palpation. The pulse is 80 , and of low tension as shown by sphygmogram. Examination of the blood showed hamoglohin, 80 per cent; corpuscles normal. The urine contained a few red corpuscles.

CaSE IX. Hemoplygis; tuberculonis; acro-asplyxia.-M. M., a drug clerk, a native of Russia, of fair complexion, light hsir, blue eyes, applied at the Philadelphia Polyclinic, February, 1893, on account of pulmonary hemorrhages. Attention was attracted to the blueness of his hands. This was said to have manifested itself while out of doors during cold weather for sereral years, and to slowly fade into $n$ pinkish tint while the patient remained indoors. Elevation caused very gradual disappen rance of the discoloration. The heart was normal. There was found slight dulness and crackling nt the left apex, and large and small mucous ratles orer hoth sides of the chest. After repeated exnnination of the sputa a few tuhercle bacilli were found. The patient stated that his mother's hands were similsr to his, ns were also those of one sister and one hrother younger than himself. His father and his elder brothers and sisters did not exhibit it. The sister and brother who had hlue hands were quite suhject to bleeding from the nose; with the sister, epistaxis censed with her first pregnancy.

This patient showed dermographism and factitious urticaria. There was no cardiac lesion, and no abnormality of the thy roid gland. His hands nnd feet wero constantly aweating both in hot and cold weather. He hsd paroxysms of polyuria. His urine while under ohservation showed occasionally red hloodcells, no al humin, no sugar, no excess of urates. Ife has myopic astigmatism (Dr. Jackson). Ender treatment, with rest and calcinm chloride, the pulmonary bemorrhares censed, and the hands improved while kept wrapped in cotton, and treated daily with a descending galvanic current.

In these cases of blue hands, and in many others of which I have record, there is a striking series of phenumena to he ohserved, which $I$ have not thought it necessary to relate in detail in each case. If, during a period of quiescence, that is to say, in warm weather, or after the effect of trcatment or of the warnth of the room has made the hands somewhat less hlue, one hand he placed in ice-water, it will, in a few minutes, hecome a hright red, while the ather hand, not exposed to local cold, becomes a deep hlue. Control ohservations on normal hands do not show the same result. If, during an attack of local asphyxia, the hlue hands be placed in warm water, one of two things may occur: 1st. The hands may quickly become red. In that event, on removal from the warm water the red fades to a lead-white, then the normal color returas, then an ahnormal hlueness. Stroking the hands, either up or down, increases the rapidity with which the whiteness derelops-and in some few mild cases, stroking alone, without resorting to immersion in cold water, will produce it. $2 \mathrm{~d}$. In other cases the hands hecome white on immersion in warm water, nnd red or pink when removed 
in to the nir. In nll cases, whether the hands be blue, pink, red, or mottled, pressure produces a whiteness which does not quickly disappear. In some cases the experiment was mnde of immersing the hlue hands, during an attack, in cold water. They would either hecome red nnd warm, or almost hlack nnd intensely cold.

I have nlluded to the nppearance of the finger-unils. Setting nsidc the well-known appearance in typical Rnynaud's disense nud that produced by pnnaris, to which latter nffection tbese suhjects seem quite prone-I hnve ohserved mnny varieties thnt fnll into two groups: a clubbed fiuger-end, with brond nnd flat, or Hippocratic parrot-benk nail; nnd secondly, a tapering finger-end, with loug nud transrersely curved nail. The uails are usunlly striated, sometimes thickly ridged longitudinally. They nre sometimes n bluish, soutimes a purplish, sometimes $n$ pink color. The broad, flat nnils are more frequently $n$ leaden blue; the long nails, more often pink. Both the pink and the blue nails exhibit crescentic markings. In the pink uails there is usu. nIly one narrow nud deep-red crescent between two wider and whitish crescents near the tip. The fint, lenden-colored nnils usually show one wide, whitisl cresceut centrnlly. These markings differ from the whitish or reddish discoloration produced by varyiug pressure in normal persons.

To resume the development of our circle of cases, I have now to submit two instances that would be merely curious in themselves, but find plnce nnd explanntion through each other, especinlly in rclntion with the cases of hxmoptysis nnd hxmntentesis recorded, and with the occurrence of bloodspitting in Graves'a disease. I bnve seen two enses of licmoptysis in exophthalmic goiter, in both of which pulmunnry tuberculosis finnlly developed.

CASE X. Paroxymal numbness of extremitics; chloroxis; hemoplysis; pulmon. ary tuberculosis; acule hemorrhagic varices (9) of pharynz.-Bliss V., of A merican birth and parentage, Scotch descent; fnir complexion, hrown.gold hair, gray-brown eyes; not hysterical; first had indications of numbness in the left hnnd and $\mathrm{nrm}$ on nearing the menstrunl period at the nge of fourteen years. Previous to this she had enjoyed good health, with the exception of an ahscess on the left side of the neck, at the age of eight, nnd frequent paroxysms of hard, larking cough. She was suhject in warm weather to nn eruption on the hnnds, wbich was relieved by applications of hlnek wash. The frequency of theattrcks of numhness and their extent continued to increase until the nge of twenty, when the patient was treated for ansemin. She had then liad no menstrual period for six months, had lost flesh, was very pnle, had cough, and constnnt headache. At this time the patient came under my care (1883) for pulmonary hemorrhages with fever, and physical signs of tuberculous infiltrntion of left apex. Under treatment complete recovery ensued; the menses appeared and the general tone of the health was restored. The numhness disapperred for ahout four years; when the attncks returned, nnd still occur, with not so much frequency but more severity, and affecting likewise the tongue nnd throat. The face hecomes very pale; the arm and hand seem perfectly lifeless, and can he placed in almost boiling water. When feeling is restored $n$ violent headache follows, and the pntient is weak for two days. The attacks generally follow disorder of the stomach or mental distnrhance, or occur ahout the menstrual period. At times, not connected with the nttacks of numhness, 
there occur in the thront during glntition, what she terms "hlood-hlisters," which consist of little hluish elevations ahout the size of half-a-pea, and apparently of the nature of varices, that when ruptured, artificially or spontaneously, discharge hlack hlood. Her sister is subject to similar hut larger "ilood-hlistcrs," which however, do not always discharge themselves, and it is said that it is sometimes necessary to puncture them to prevent suffocation. Her grandmother was liable to attacks of numhness, from ahout the age of thirty until the age of eighty.

This patient exhihits dermographism, factitious urticaria, and the eye-sign. Her nails are curved, pink, marked with crescents. She has hyperopic astigmatism (Dr. Turnbuil). The thyroid gland is not enlarged; there is no heart lesion.

CASE XI. Blue cellems of pharynx and uvula, with urticaria of fundament; angio-neurolic adema of trunk and face; paroxysmal tachycardia. - Mrs. B., aged sixty years, on June 20,1892, complained of sudden dyspncen of a few hourg' duration, and soreness of the throat. For a day the patient has had urticaria of the fundament. She is suhject to this form of urticaria at irregular intervals. The urula is swollen, more upon the left, and the mucous memhrane is of a grayish-hlue color; the left posterior palatine fold is similarly discolored and cedcrnatous. The swellings pit upon pressure. Scarification gives exit to less than a drachm of black hlood. Tro or three days ago the patient had, without known exciting cause, an attack of sudden violent beating of the heart. She hecame quite faint, and lay down, and in the course of ahout half an hour the heart hecame quiet. An attack less riolent and of shorter duration occurred later in tho day. The attacks were accompanied with lushing and heat of the entire hody. The patient has not meastruated for some years. Slie has had similar attacks previouly. The first followed a meatal shock twenty years ago. The attacks usually jast twcaty four hours. Different portions of the body are swollen. Once the cedema occupied half the face; nt another time half the ahdomen. On three occasioas it has begun in half the lip, afterwards extending to the whole structure. The tongue has been strollen.

Her urine, examined on the day following the attack reported, was amber in color, turhid, acid reaction, specific gravity 1019, coataiaiag ao albumia, no sugar; leucocytes and red cells were present.

The patieat exhibits dermographism and factitious urticaria. She is aot specially susceptible to cold. Her family, while loag-lived, is gonty and neurotic. One of her daughters has aggravated hysteria. One sister has diahetes mellitus. This sister likewise exhihits dermographism and factitious urticaria, and as a child and young woman was subject to paroxysmal flushing of onc cheek.

The following case will serve as a transition to a comparatively large group, in which digestive disorders are promineat.

CAsE XII. Hysteria; burning and coldness of exlremilies; herpelic (?) eruption; hungry dyspepsia; exophthalmos.-July 11, 1892 . Mrs. R. O'D., a typical hrunette, of American hirtl, French parentage, nged twenty-five years; complains of suhjective and ohjective coldness of the legs helow the knee, for a week. There is cold perspiration of the feet. For a year the patient has heen feeling worn out and languid. During this time the hands hare heen swollen, red, and hurning when she rises in the morning. The redness passes off quickly.

Sometimes there is a similar condition for half an hour toward evening. The patient is hysterical and easily frightened-the heart palpitates violently when she is nervous or excited. For three months suhjective vertigo has occurred at irregular intervals. There is no dimness of vision; she sees neitler flashes of light nor dark specks. Ten years ago she had " a fainting spells," in whicli, however, she did not lose coasciousness. She hecame dizzy, then clenclied lier teeth and hands, and fell; the image of the last ohject seen remained impressed on the retina. The attack lasted a few minutes; there was no convulsion, no subseqnent drowsiness. There have heen six such 
attucks in one day; they have hecome less frequent since marriage; the last was gix months ago.

A hout a yenr ago there would, from time to time, nppenr on the legs and disappear after ahout two days, a pupulo-resicular eruption associated with itching. It did not pustulate and dried without scahhing. The howels are constipated. There is hendache. Sometimes tliere is pain referred to the stomach and relieved by eating. There is no nausea, no vomiting, no pyrosis. Appetite is excessive. There is no polydipsis. The urine is excessive in quantity, ond the patient rises at night to urinnte. Menstruation is irregular. The eyes are prominent, the eyelids tremble when closed. The sclern is exposed when the eyes are opened. The refiexes are all exaggerated. The heart is irregulnr, not specially rnpid; no murmur. The thyroid gland is not enlarged. UTrine: acid, 1013, no alhumin, no sugar; numerous disks that may he decolorized red cells. (Dr. Eshner.)

The phenomeno of disturbed and incoördinote circulntion nre often eren more strikingly monifested in the cases diagnosticnted of recent years as " neurotic dyspepsin" and "neurasthenia." In this connectinn I will briefly enunerate the salient features only, of two ndditionnl cases.

CAse XIII. Neurasthenia; lithamia; vertigo; membranous enteritis.-MIr. J., aged thirty years; attorney; American Hyperopic astigmntism; nausea; no romiting; paroxysms of sertigo, with pallor, chillio ess, nnd sweating; aggrnvated oeurotic dyrpepsis; Invage proves ahsence of morhid secretion; emaciation; inability to attend to husiness; morhid nttention to symptoms; no heart or luog lesion; throhhing nnd murmur in nhdominal aorta; exaggerated reflexes; mottled honds; pint;, crescent-marked noils; dermogrophism, foctitious urticario; eje-sign; poroxysms of polyuria Urine cootains no nlbumin, no sugar; nt times leucocytes, red cells, uric ncid, calcium oxnlate, phosphates. Patient has memhranous eoteritis. Has had attaclis of urticaria ; is extremely susceptible to hoth heot and cold; hands and feet frequently hecome cold without apporent cause. His child has o curious mottling of the skio of the trunk ood limbs that resemhles measles. At times it is of a visid red, ot others it fades to a delicate pink or fnint browo.

CASE XIV. Hysteria in a male, with neurotic dyspepsia, hamalemesis, par. oxysmal fiushing, and sexual crises.-The priocipol points io this case, of which space forhids o full report nt present, are as follows: The patient, $n$ mercliant, aged forty-five yeors, aod happily married, is highly emotioonl and of on hysterical fnmily. He is stout, henvily huilt, with red cheeks, and duskypink hands. His nails are of the lenden-blue variety. Dermogrnphism, the eye-sign, and the costal fringe are present. Factitious urticaria can readily he produced, and the patient has had hives repeatedly. He is quite sus. ceptible to moderate heat, flushing nnd perspiring when others feel comfortahle. He has a hnhit of working feverishly, and is ao interminahle talker. After a period of overworl his digestion fails. He has burning pain in the stomach, with excessive thirst, nnd innhility to retain anything except iced liquids. There are crises of gastric and ahdominal cramp with vomiting-at times vomiting of hlood-with serous diarrhoea, and nt times passnge of memhrane. He does not use alcohol or tohacco, and alwnys has heen chaste. At times when suffering with indigestion, he will have sudden sensations of heat in the hend and colduess below the knees; or general heat followed hy chilliness; which, as he lives in a malarious region, has heen called malaria. A peculiarly distressing form of the paroxysm is a feeling of heat hegianing at the navel and spreading over the hody, with pain in the testicles and unnatural sexual imaginings provoked hy the gight of a strange man or woman " perhaps ugly as Sntan ;" his face hecomes dusky red and his whole body tremhles. This is followed hy insomnia, anorexia nerrosa, and finally for two or three nights hy excessive nocturaal micturition, the urine heing colorless as water. Such nrine has a specific gravity of ahout 1002, and contains nothing ahnormal. His_ordinary urinelcontains neither'alhumin nor sugar. On two occa 
sinns colorless hlnod-cells were found in large guantities. His hlnod is apparontly normal, nnd when exnmined in Philadelphia during a paroxysm of suhjective heat, without elevation of general temperature, malarinl organisms could not be found. Larage proved entire ahsence of gastric catarrh, nnd examination of stomach-contents a fter test-hreakfiast showed nbsence of free neid with diminished total acidity. The eyes nre normal. The knee-jerks nre sluggish. The heart is slow $(60)$ and feehle; dilatation not demonstrahle. There nre attacks of palpitation with dyspnca. The ahdomen is not sensitive to pressure. Hepatic dulness is normal. The splenic dulness is not enlarged.

In some cases of vasomotor ataxia there is a pronounced idiosyncrasy toward drugs; the most remarkable instance I have seen being the following:

Case XV. Paroxysmal headache and vertigo; circumseripl adema caused by strychnine and by pieroloxin.-DI $\mathrm{r3}$. E.S., aged forty-seven years; of American nativity and parentage ; dark hair and eyes; full hnhit, flushed face; ras secn in Aprif, 1890. She complained of paroxysmal hendache, suhjective vertigo, and fiushes of hert; the symptoms being of several years' duration. There is no visual disturhance. Headache and vertigo occur tngether or independently. The headache is not localized, hut sometimes there is a feeling as of whirling inside the skull, in the vertical region. At times there is a sensation as of cold water heing poured down the hack. There is no rheumatic or other personal or family morhid history. The patient is regular in menstruntion. There is no indigestion, hut the howels are inclined to be constipated. The thyroid gland is not enlarged; there is no thrill or bruit. There has heen no urticaria, nor can factitious urticaria he produced. Dermographism is marked. The nails nre pink and purple; they are strinted and exhibit pink nnd white crescents. The hands are always warm, frequently sweating. The feet are cold even in warm weather; at times there are paroxysms of icy coldness, without loss of sensation or change of color. The urine is scanty, less than a guart in twenty-four hours; it contains nothing nbnormal. The pupils are much dilated. Dr. Hansell examined the eyes, and reports " presbyopia, no lesion of fundus, veins overfilled." The heart is slow and steady (rate 60 ), the pulse is full hut not strong; superficinl veins are not prominent. Strychnine (o grain t. d.) administered medicinally caused marked cedema of the fuce. The patient recalled a previous experience of the same kind. Nux vomica and picrotoxin caused similsr effects. Hyoscyamine reliered the hesdaches; nlknline diuretics increased the urine. The patient improved, but passed out of ohservation. August 31, 1893, she reported at request. She is going through the menopause. The flushes of heat are more frequent. The liead, neck, chest, nnd nrms to the finger-tips become red. The redness passes off in $\mathbf{n}$ few minutes. Sometimes it is accompsnied hy $\mathrm{a}$ numbness of the left hand nnd arm, nnd tingling with coldness in the last two phalanges of all the fingers. Sometimes the numhness will last for two hours after the redness has disappeared. A second flushing may necur hefore the numhness cerses. There is no periodicity in these occurrences. Perhaps they are worse when constipation exists. The hands are usually warm and moist, the feet cold. Immersing one hand in ice-water it hecomes quite red and slightly swollen. The wrist and forearm hecome hlue in patches, with marked distention of venules. The hand is ohjectively cold, suhjectively warm. The other hand is not changed in color, but quite cold. On remning the reddened hand from the cold wnter the finger-tips first hecome white and numb, hut nfter a few minutes redness returns, with a sensation of pins and needles, and hoth suhjective and ohjective warmtb.

Not now to detail additional instances, it may be stated that among other morbid associations found in cases of the same general character as those reported bave been ecchymoses, petechix, hamaturia, retinal 
hemorrhage, organic heart lesion, nrganic kidney lesion, chorea, rheumatism, hay fever, pnroxysmal engorgement of turhinate hodies, angina pectoris and pseudo-angina and glycosuria. In one case lamoptysis occurred only during epileptic paroxysms; in another case of epilepsy, tachycardia and flushed face accompanied the convulsion. In both these cases there was a soft enlargenent of the thyroid gland.

The obscurity in which the pathology of diseases of the sympathetic, or, to use Gaskell's term, the visceral nersous system, is still involved, cautions against premature assertion of other than clinical facts.

I helieve that the phenomena herewith suhmitted for consideration are of considerable clinical sigaificance.

Leaving out of consideration for the present, the diseases other than exophthalmic goitre (acromegalia, myxoedema) known to bs associated with abnormality of the thyroid gland, there are four affections of grent moment in which fuuctional or structural alteration of some portion of the visceral nervous system is an important element, if not the essential feature. These are Graves's disease, Raynaud's disease, Addison's disease, nnd certain forms of diabetes mellitus.

The cases bere reported show the existence of lescer degrees of disturhance of that system; and indicate that in some instances, at least, there is a congenital tendency to such disturhance. They suggest, more. over, that this congenital wnnt of halance in the circulatory npparatus may be the germ from which, under the fructifying influence of vnrious exciting çuses, the more serious disorders develop. Thus mental or even physical shock in a subject of congenital vasomotor ataxia might cause the sudden development of exophthnl mic goitre; and nn exposure to cold from which a normal indiridual would quickly renct, causes, iu the suhjects of this condition, local asphyxia, chilblnins, frost-bite, or even extensive gangrene. So too, slight indigestion, itself ths result of influences thet would he ineffectual in a normal iadividual, may, in the subjects of vasomotor ataxin, induce crises of vertigo, migraine, syncope, or even pnroxysms of epilepsy. And similarly, other sources of peripheral irritation-eye-strain, nasal abnormity, exposure to pollen, and the like, result in the production of an exaggerated reaction. The relationship of hay fever with the group of cases under consideration, may he hest exhihited hy comparing two of the descriptive names it has received-"idiosyncratic coryza" (J. Solis-Cohen) and "periodic vasomotor coryza" (J. N. Mackenzie). One of my patients with hlue hands, was compelled to gire up his position in a drug house hecause of his excessire susceptihility to ipecacuanha.

The occurrence of diahetes mellitus in memhers of the families ot patients exhibiting the phenomena of vasomotor ataxia ; of intermittent glycosuria in one of my cases of menstrual migraine with urticaria and almost constant flushing of the fuce; and of intermittent polyuria ia 
many of my cases, are circumstances worthy of note-especially in relation with the occurrence of glycosuria in some cases of Graves's disease, aud witb the investigations of Thireloix upon pancreatic diabetes.

Tbe tendency to hemorrbage must not be overlooked, especially in connection witb the diagnosis of pulmonary tuberculosis, of gastric ulcer, and of hypertrophy of the heart. Cases sucb as those I have reported may develop tuherculosis or cardinc hypertrophy, hut these conditions need not necessarily he present at the time of hemorrhagc, or later. I would call especial attention to the extraordinary frequency with which, in cases of vasomotor ataxia, rel hlood.cells are found in urine not dis. colored-a fact rendered significant to my mind hy personal ohservation of hrenaturia in a case of undeveloped Graves's disease that later exhihited the full complexus of symptoms, and by the records of bremnturia and hemoglobiuuria in Raynaud's disense. Unfortunately, the single case of paroxysmal hxinoglobinuria from cold that has come under my observation was not studied from tbe standpoint of tbe present paper, and is not available for comparison. In this connection, too, an intereating relation with hemopbilia, and with the purpuric growp of affections is suggested; but it would not bc advisable at present to more tban indicate this subject.

The frequent association of refractive crrors, and especially of byperopic astigmatism, with iustability of tbe circulatory equilibrium, raises the question wbetber tbe ocular defects are to be classed in the category of exciting causes acting by reflected irritation, or whetber tbere is a more fundamental relation. I an inclined to the opiuion tbat abnormity of circulation and nutrition hears a causative relation to the ametropia. The eye-straiu may tben react additionally upon the centres, increasiag their irritability.

Finally, as exenplified by the case which frit drew my attentiou to the subject (Cuse III.), and by the case last reported (Case XV.), we must recognize $n$ class of cases to which, as yet, no definite nosological place has heen given, and in wbich a varied symptomatology of circulatory disorder connot he referred to disease of any organ; though lesion of the digestive tract, of the kidney, of the heart, or even cerehral or spinnl lesion may be suggested. For these cases, depending as thcy must, upon a want of control in the nervous system governing tbe calibre and tension of the vessels, a defect clearly of inbibition, and hy the radius of its effects evidently central in location, it seems to me tbat the most appropriate name is vasomolor aturia.

\section{SUMMLARY.}

1. By the term vasomotor ataxia it is proposed to designate tbe condi. tion of instahility of tbe mechanism of circulation present in certain persons and chnracterized by abnormal readiness of disturbance with 
tnrdiness of restoration, of the equilihrium of the cardio-vascular nppnratus. The mnnifestations are most strikingly displayed hy the benrt and hy the peripheral vessels of the extremities, hut analugy indicates the occurrence of similnr phenomenn in the vessels of the glands and of the viscern, more especinlly in those of the kidney, of the gastro-intestinnl tract, nnd of the hrain. They may occur appnrently spontnneously, hitt often there is a recoguizable exciting enuse. .Among the iufluences acting as excitants, nre tempernture, especinlly cold ; toxic agents formed in the hody, or introduced from without; visceral or intcrnal reflex excitation; nnd emotion. The stimulus may he npplied centrnlly or peripherally, hut in cither case the resulting phenomenn indicate a defect of centrnl inhibitiou; the expression, prohnhly, of functional or uutritional aherration in the great ganglin of the visceral nervous gystem, in the medullary centres, or in both. The morbid anatomy is nncertain, and the results of necropsies necessarily inconclusive.

2. Vasomotor ntnxia may he acquired as $n$ sequela of disease; in many cases it is cougenital; in some cases inherited; the condition is not mrely present in severnl memhers of $n$ fnunily.

3. In some cases the phenomenn nre of paretic, in others of spasmodic chnracter. Usunlly the two kinds of phenorena nre displayed in vnrying degree in the same pntient. Whether spasmodic or pnretic the symptoms nre suggestive of incoördinntion. They nre nlways in sonse degree pnroxysmnl.

4. In exophthnlmic goitre, especinlly such cases as nre produced hy emotion or are murkedly intermittent, is found the extreme type of the "relnsing" vnriety of vasomotor ntaxin.

5. The form of Rnynnud's disease, known as "local syncope" furnishes nn extreme type of the "constrictive" vnriety ; while "locnl nsphyxia" exhibits phenomenn of hoth nbnormal relaxation nnd nhnormal constriction of the vessels.

6. Between these extremes are numberless gradations down to the slightest departure from normality; while eveu the extreme symptomgroups represent merely exnggerations of phenomenn thnt under certnin conditions occur in normal individunls.

7. Dermogmphism is nu essential feature of vasomotor ntaxin, nnd in most cases factitious urticarin can be readily produced hy cold or hy pressure or by hoth; mottlings of the skin, certain peculinr markings of the nuils, telnngiectases, and stigmnta a re common.

8. There is usually $\mathrm{n}$ hemorrhngic tendency, as shown by ecchymoses, petechiæ, epistaxis, hæmoptysis, hæmntemesis, hænınturia, and rctinal hemorrhage.

9. Even in the nhscnce of hrematuria, red blood-cells are often found in the urine; uric ncid, urates, and oxalates nre likewise common; the 
presence of nlhumin, tuhe-casts, and cylindroids is less common, and is usually intermittent. Glycosuria has been ohserved.

10. In many striking cases there has appeared to he morbid alteration of the thyroid gland.

11. The action of the heart is usually rapid, irregulnr, and easily disturbed; pnlpitation is common, and intermittent tachycardia has been noticed. Hæmic and functional murmurs are not uncommon.

12. Among other symptoms and morbid associations ohserved are anæunia, lysteria, drug idiosynernsies, urticaria, local œdema, hyperidrosis, angina pectoris and pseudo-angina, organic heart disease, pulmonary tuherculosis, asthmn, hay fever, vertigo, migraine and other forms of hendache, transient hemiopia and other visunl disturbanec, persistent nydriasis, astigmatism, myopia, hyperopia, menstrunl irregulurities, intermittent polyuria, rheumatism, rheumatoid arthritis, contractures of digits, chorea, epilepsy, neurasthenin, neurotic dyepepsin, gastralgia, enteralgin aad membranous enteritis-most of which are douhtless fundamentally relnted, as effects of n common eause, or as secondary results.

13. Ia makiag the diagnosis of simple vasomotor ataxin, it is neecssary to exclude primary orgaaic disease. The occurrence of such disease later does not invalidate tbe original diagnosis. The development of pulmoanry tuberculosis ia some cases is prohahly a sequence of vascular and trophic disturbance in the lung. Cardiac hypertrophy and renal lesion may likewise be amoag the results of disordered circulation.

\section{TOX AEIIA OF PREGNANCY: ITS DIAGNOSIS AND TREATMENT."}

By Enwarn P. Davis, A.II., JI.D.,

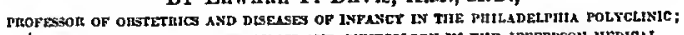
CHINICAL LECTURER ON OBSJETRICG AND GYNEOOLOGY IN TJE JEFFERSON NEDICAL. COLLEGE; VISITLSG OLSTETRICAN TO THE PHILADELPHA HOSPITAL ETC.

Br the term toxcenia of pregnancy we understand $\mathrm{n}$ condition oceurring in the pregnant woman in which toxic material is present in the hody in excess. There can he nn nutrition without the production of waste, and when the dunl existence in the hody of the pregnant patient is considered, it is not strange that an additionnl qunntity of waste products is present. The excretion nf this material is effected largely through the ngency of the kidneys, and bence attention was first nttracted by those cases where kidney failure was the first and prominent symptom; hut as our knowledge of pnthology is increased, we see that 